\title{
COMMUNICATION
}

\section{THE EDUCATION AND PROFESSIONAL ACTIVITIES OF WOMEN}

\author{
By Sophie Yudelson.
}

The direct relation a given social system bears to the employment and consequently the education of women may be illustrated by comparing the educational status of southern women with that of the women in the western states.

The South, for years a slaveholding community, has in a remarkable way reproduced, in matters feminine, the old ideals of the Old World civilization; a general depreciation of woman's labor and a spirit of romantic chivalry, combined with a desire for a separate "sphere." "We find accordingly the sentimental sex attitude everywhere prevalent discouraging any progressive movement of woman, and forever advocating the domestic standard as an all-absorbing and sufficient profession." 1 Accordingly "they study at a high school or academy such things as befit their position as young ladies whose business is to be charming and whose destiny is marriage." "It is recognized as a necessity that some women must support themselves, but at the same time it is considered a cause of regret. . . . There is a covert apology for the professional woman, a kindly-intentioned explaining away of her labor from the mouth of her friends. . . . A striking proof of this is the gratuitous remark often heard that the woman who works is deserving of just as much respect as the one who does not." " Furthermore, "the woman worker in the South is an object of sympathy if purely static; of aversion if dynamic and independent." Hence, "in the catalogue for I889 in the Norfolk College for Young Ladies, the aims of the school are said to be molded in accordance with the principle that a woman's province in life is to throw herself heartily into the pursuits of others rather than to have pursuits of her own." * A little training in French and music, and some study of English literature, are generally supposed to be sufficient for that.

However, changes are being wrought even in the old South. The system of economic activity introduced after the abolition of slavery created a demand for women's work. This demand seems to have a wonderful effect on college curricula for girls. For instance, the Georgia Female College, established in 1839, prescribes "Harkness' First Year in Latin" as the only preparation in

1 Arena, I 899, p. 755.

P. 745 .

P. 748 .

4Annie Nathan Meyer, "Woman's Work in America," p. 90.

(I17) 
languages for entering the freshman class and plane geometry is a sopohomore study. The Industrial Institute and College at Columbus, Miss., established in 1885, gives in its collegiate course analytical geometry, Juvenal, metaphysics, political economy, etc.; calculus, descriptive geometry, quantitative analysis and the history of philosophy are among the subjects offered in postgraduate courses. ${ }^{.}$The study of these and similar subjects may not be of special value to certain husbands, but practical employers, willing to pay respectable salaries, demand thorough training as a prerequisite; and conscientious husbands, who prefer bookmaking to slaveholding, seldom fail to note in their prefaces the obligations to their wives.

Turning now to the West, one does not find that a separate "sphere" for women was ever considered desirable. Instead of inquiring how much or how little education woman should receive, there was the extreme opposite discussion as to whether or not women should be educated together with men. This discussion has resulted in the fact that "at the present time in the western states and territories the higher education of women is generally identical with coeducation." Writing, in I890, on the "Education of Woman in the Western States," Mary W. Sewal gives the following facts:

"I. Of 212 institutions, exclusive of colleges of agriculture and mechanic arts, which afford the higher culture to women, I65 are coeducational.

"2. Of the 5,563 women reported to the Bureau of Education in I887I 888 as students in the collegiate courses of these institutions, 4,392 were in the coeducational colleges.

"3. In the twenty states and territories which boast 165 coeducational colleges and 47 colleges for the separate education of women . . . there are but 25 colleges devoted to the exclusive education of men.

" 4 . Of these 25 institutions not one is non-sectarian and they are all supported by the Roman Catholic, the Protestant Episcopalian, the Lutheran or the Presbyterian denominations. In several of the states most conspicuous for zeal in the cause of higher education as in Michigan, Iowa and Kansas, not one college for the exclusive education of men exists."

Has this state of affairs been brought about without a struggle? Surely not. The history of woman's education tells convincingly of the bitter opposition woman has met at every step in her fight for the right to instruction, everywhere, East and West, North and South of the United States.' As far as coeducation is concerned, even after it "has become a fact," says Mary W. Sewal, "the whole question was reopened in a new form by the attempt to exclude women from Adelbert College of the Western Reserve University, which had already been open to women for twelve years." "Every reason which had formerly been urged against the admission of women was now offered for their exclusion." Physical inability and mental inferiority, individual respectability and social conventionality, domestic calamity and moral impropriety, all these were earnestly and solemnly urged against coeducation. But in vain. The force of prevailing conditions was irresistible. The sparse-

Meyer, p. 105.

- Meyer, p. 65 .

See interesting account in Meyer's "Woman's Work in America." 
ness of population and the difficulty in getting "hired help" brought men and women to work together in field, office, shop and household, in church and school. "Thus without intention on the part of either men or women, they become used to working together in many unaccustomed ways; and the idea of going to college together does not seem so unnatural as in older communities, where traditions of old standing have separated men and women in their occupations." " Coeducation triumphed. By the nature of things it could not be different. "Among the Clatsops and the Chinooks who live upon fish and roots, which the women are equally expert with the men in procuring, the former have a rank and influence very rarely found among Indians. The women are permitted to speak freely before the men to whom, indeed, they sometimes address themselves in a tone of authority."

The effect of coeducation, in its turn, on the whole woman question, both theoretical and practical, cannot be overestimated. First, although coeducation itself does not indicate that women are mentally equal to men in assimilating, reorganizing or reproducing acquired knowledge, it does prove that women can comprehend the same studies. This at least points out the necessity that the old theory of the feminine mind must be revised. Second, "men who have studied with women in college almost invariably favor their admission to county and state, medical, legal and editorial associations; and thus . . coeducation prepares society to give women welcome and patronage in business and professional life." ${ }^{10}$

In general, the educational status of woman is very high. One rarely, if ever, hears that women must not be educated because they are women. The most one does hear is that their higher education, for one reason or another, is not profitable, not practical. Elementary education, as a rule, is compulsory for boys and girls alike. According to the last census, the aggregate number under school attendance is $6,668,823$ for males between the ages under 5 to 21 years and over; the number for females of the same ages is $6,698,324$, the girls leading in numbers between the ages under 5 to I7 years inclusive.

The advance that is being made by women in higher education, in spite of occasional remonstrances, may be seen in the accompanying table taken from the report of the Commissioner of Education for 1902.

This table shows an enormous increase in women students during a very short period. In $1889-90$ there were 10,761 women against 44,926 men students, the latter 4.17 times as great as the former. In I901-1902 the number for women was 29,258 against 78,133 for men, the latter only 2.67 times as great as the former.

\footnotetext{
Meyer, p. 71.

- Spencer, "Principles of Sociology," p. 732.

10 Meyer, p. 82.
} 
NUMBER OF STUdents FOR EACH YEAR FROM I889-I890 to Ig0I-I902."l

\begin{tabular}{|c|c|c|c|c|c|c|c|}
\hline \multirow[t]{2}{*}{ YanR. } & \multicolumn{2}{|c|}{$\begin{array}{l}\text { Universities and } \\
\text { Colleges for Men } \\
\text { and for Women } \\
\text { and for Both Seres. }\end{array}$} & \multirow{2}{*}{$\begin{array}{c}\begin{array}{c}\text { Colleges } \\
\text { for } \\
\text { Women. }\end{array} \\
\text { Women. }\end{array}$} & \multicolumn{2}{|c|}{$\begin{array}{c}\text { Schools } \\
\text { of } \\
\text { Technology. }\end{array}$} & \multicolumn{2}{|c|}{ Total Number. } \\
\hline & Men. & Women. & & Men. & Women. & Men. & Women. \\
\hline $1889-90 \ldots \ldots \ldots$ & 38,056 & 8,075 & $x, 979$ & 6,870 & 707 & 44,926 & $10,76 I$ \\
\hline $1800-91 \ldots \ldots \ldots$ & 40,089 & 9,439 & 2,265 & 6,131 & $48 I$ & 46,220 & 12,185 \\
\hline $18_{9 \mathrm{I}-92} \ldots \ldots \ldots$ & 45,032 & 10,390 & 2,636 & $6,13 I$ & $48 I$ & 51,163 & 13,507 \\
\hline $189_{2}-93 \ldots \ldots$ & 46,689 & I 1,489 & 3,198 & $8,6,6$ & 843 & 55,305 & I 5,530 \\
\hline $1893-94 \ldots \ldots$ & 50,297 & 13,144 & 3,578 & 9.517 & 1,376 & 59,814 & I 8,098 \\
\hline $1894-95 \ldots \ldots \ldots$ & 52,586 & 14,298 & 3,667 & 9,467 & 1,106 & 62,053 & 19,071 \\
\hline $1895-96$ & 56,556 & 16,746 & 3,910 & 8,587 & 1,065 & 65,143 & $21,72 I$ \\
\hline $1806-97 \ldots$ & 55.755 & 16.536 & 3.913 & 8,907 & 1,094 & 64,662 & 21,543 \\
\hline $1897-98 \ldots \ldots \ldots$ & $58,4 \circ 7$ & 17,765 & $4,4 \times 6$ & 8,611 & 1,289 & 67,018 & 23,470 \\
\hline $1898-99 \ldots \ldots \ldots$ & 58,467 & I 8,948 & 4,593 & 9,038 & $I, 339$ & 67,505 & 24,880 \\
\hline $1899-1900 \ldots$ & $6 \mathrm{r}, 8 \mathrm{I2}$ & 20,452 & 4,872 & 10,347 & $I, 44^{\circ}$ & 72,159 & 26,764 \\
\hline $1900-1901$. & 66,069 & 21,468 & 5,260 & 10,403 & 1,151 & 75,472 & 27,879 \\
\hline $1901-1902 \ldots \ldots$ & 66,325 & 22,507 & 5,549 & II, 808 & $I, 202$ & 78,133 & 29,258 \\
\hline
\end{tabular}

Reports received at the Bureau for the scholastic year ending June, 1903, show that 4,917 educational institutions of various grades had 240,697 students pursuing commercial or business studies, 134,967 men, 105,730 women.

\section{The Professions.}

Teaching.

In his report for 1900 the Commissioner of Education states that in the past ten ${ }^{28}$ years women students increased by $I_{4} 8.7$ per cent., while men students increased by 60.6 per cent. This large increase would have remained an enigma if we could not explain it by the growing number of women engaged in professional work, ${ }^{13}$ as shown in the followng table:

\begin{tabular}{|c|c|c|c|c|c|c|c|}
\hline \multirow[t]{2}{*}{ State OR TERRitory. } & \multicolumn{2}{|c|}{$\begin{array}{c}\text { Whole Number of } \\
\text { Different Teachers } \\
\text { Employed. }\end{array}$} & \multicolumn{5}{|c|}{ Percentage of Male Teachers. } \\
\hline & Male. & Female. & r870-r. & $1879-80$ & $1889-90$ & $\begin{array}{r}1890- \\
1900 .\end{array}$ & $1901-2$. \\
\hline $\begin{array}{l}\text { United States ......... } \\
\text { North Atlantic Division } \\
\text { South Atlantic Division } \\
\text { South Central Division. } \\
\text { North Central Division. } \\
\text { Western Division ..... }\end{array}$ & $\begin{array}{r}122,392 \\
18,069 \\
19,567 \\
30,652 \\
48,152 \\
5,952\end{array}$ & $\begin{array}{r}317,204 \\
90,003 \\
31,818 \\
34.848 \\
139,691 \\
20,844\end{array}$ & $\begin{array}{l}41.0 \\
26.2 \\
63.8 \\
67.5 \\
43.2 \\
45.0\end{array}$ & $\begin{array}{l}42.0 \\
28.8 \\
62.5 \\
67.2 \\
41.7 \\
40.3\end{array}$ & $\begin{array}{l}34.5 \\
20.0 \\
49.1 \\
57.5 \\
32.4 \\
31.1\end{array}$ & $\begin{array}{l}29.9 \\
18.4 \\
40.7 \\
47.4 \\
28.3 \\
24.7\end{array}$ & $\begin{array}{l}27.8 \\
16.7 \\
38.1 \\
46.8 \\
25.6 \\
22.2\end{array}$ \\
\hline
\end{tabular}

11 Report of the Commissioner of Education for 1902, Vol. II, p. r349: Ibid., p. 2003.

$121889-90$ to $1890-1000$.

12 Report of the Commissioner of Education for 1902, Vol. I, p. Ixxx. 
There are 194,812 women teachers more than men teachers in the public schools. And if salaries are a measure of efficiency, it seems that the women keep very near the masculine standard; the average monthly salaries being $\$ 49.05$ for men and $\$ 39.77$ for women. The 122,392 men teachers would surely object if we were to state that only the less efficient men are teaching. Besides, when we remember the fact that "in the law of 1789 the expression master and mistress makes recognition of women as teachers for the first time," we must admit that woman's progress in this profession was as rapid as it was great.

\section{Medicine.}

"The first empirical physicians," says Professor Mason, "were not the sorcerers, but the herb women. They gathered the first materia medica." I" "Shiphra and Puah," of the Bible, had numerous followers too. But with the development of medicine as a learned profession and woman's exclusion from all learning, the profession was completely monopolized by men. The difficulties which women encountered in partly wresting it from the monopolists we cannot here recount." Suffice it to note that "when, in 1872, the London University, after a two years' bitter controversy, declared women eligible to its degrees, the journals were flooded with letters from indignant physicians who declared that by this action their own diplomas previously obtained had been lowered in value, their contracts violated and their most sacred property rights invaded." ${ }^{10}$ In the United States it took Elizabeth Blackwell to apply to twelve medical schools of which only one, in Geneva, N. Y., admitted her. This was in 1845 . Five years later Harvard refused to admit a Harriet $K$. Hunt because of the students' protests on the ground "that whenever a woman should prove herself capable of an intellectual achievement, this latter would cease to constitute an honor for the men who had previously prized it." ${ }^{17}$ But in 1892-93 there were 1,302 women enrolled in the medical schools of the United States. There were seven medical schools for women only; 3,000 women had been licensed and 4,555 women were physicians and surgeons at practice. ${ }^{18}$

The number of women students, however, has decreased rather than increased since 1892 , and when the present number is compared with that of men students it is small. There are only $\mathrm{I}, \mathrm{I77}$ women studying medicine against 25,644 men, the actual decrease as compared with the number given for 1892 being 125 .

Among the various conditions that suggest themselves as causes.of the decrease, the most effective one is undoubtedly the ever-increasing expenses involved in the training for the medical profession. The methods of teaching medicine in the United States have been greatly improved within recent years, and with the improvement has been introduced a rise in the cost of

\footnotetext{
16 Otis Mason, "Woman's Share in Primitive Culture," p. 278.

45 See interesting chapter by Dr. M. P. Jacobi in Meyer's "Woman's Work in America."

18 Meyer, pp. 148-149, note.

17 Meyer, p. 148.

4 Report of Commissioner of Education for r 894-5. pp. 949-950.
} 
tuition, instruments, etc. In certain institutions the tuition fee alone amounts to $\$ 200$ or $\$ 250$ per year. This fact may, of course, not discourage a young man bent upon entering the profession. If parents are at all able to give their son a professional education, a few hundred dollars more or less spent during the college course is perhaps of little consequence. The case is quite different with regard to a daughter's professional equipment, probably because it may not exempt her father from giving her a "goodly" dowry, after all; while the son runs the chances of getting a "respectable" sum. If, on the other hand, a young man undertakes to study medicine with little or no assistance from his parents, he can get it in the form of scholarships, fellowships, etc. A young woman does not have the same or similar opportunities. Society has not yet made the same provisions for the medical education of women as for men. Another condition which affects directly and unfavorably woman as a practitioner is the development of the "dispensary," extending medical help gratis to those classes of the community which would most likely engage the services of a woman, if for no other reason, simply because she might not demand from them as high a price for her service as a man does.

The combined effect of comparatively small expenses during the years of training and the prospect of practicing later among the more wealthy classes or in institutions, has evidently led to woman's resorting to nursing as a profession. According to the last report of the Commissioner of Education there were, in 1902, I1,876 women nurse pupils and only 1,376 men pupils. Pharmacy and dentistry, too, have their female votaries in modest numbers, 162 for the latter and 218 for the former.

Lare.

The legal profession seems to have special difficulties for women. The number of students does not increase rapidly.

There are three important facts to be noted: x. The majority of law schools freely admit women. 2. Women lawyers are entitled to practice before all courts, state and national, "the same as men." When not admitted under existing statutes the respective legislatures, so far, with but two exceptions, have promptly passed enabling acts." 3 . Women lawyers are endeavoring to ameliorate unfavorable conditions. The "Women's International Bar Association," for instance, has for its objects: (I) To open law schools for women; (2) to remove all disabilities to admission of women to the bar and to secure their eligibility to the bench ; (3) to disseminate knowledge concerning women's legal status; (4) to secure better legal conditions for women." 20

\section{Theology.}

The Universalist Church was the first, in 1860 , to open the doors of its theological schools for the training of women for the ministry, and "by its established forms ordain them to its full fellowship." Its register for 1889

10 Meyer, p. 235.

2 Com. Report for r904-5, p. 957 . 
contains 35 women ministers. The Unitarian Church has a number of preachers, some of them regular graduates, others simply acting as "helpmeets" to their husbands. The Quakers regularly admit women as preachers. "The Presbyterians, by a vote of 93 to 24 , decided in 1889 that the ordination of a woman as deacon is in harmony with the New Testament and the Constitution of the Apostolic Church." In I893-94 there were Io students in colleges of the Congregational denominations; 6 in Baptist colleges and 4 in a Universalist college. ${ }^{21}$ The number of women in schools of theology for 1902 was $108 .^{22}$

States OR TERRITORIES. Students.

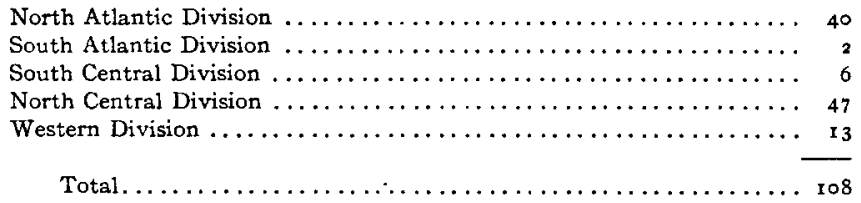

Fewer women have entered theology than the medical or the legal profession. This may possibly be explained by the fact that the ministry has not increased in popularity so rapidly as the other professions have, even for men.

21 Report for $1894-5$, p. 959 .

22 Report for 1002 . 